\title{
SOCIAL ASPECTS OF MANAGING HOMEOWNER ASSOCIATIONS
}

\author{
Magdalena Szczepańska, PhD \\ Department of Sociology \\ Kazimierz Wielki University \\ e-mail: magda1szczepanska@gmail.com
}

\begin{abstract}
The article calls attention to homeowners associations (HOAs), which are becoming the dominant organizational form of housing development. It focuses on managing HOAs, especially on the social aspects and determinants of the process. The author claims that in order to understand how HOAs function, it is absolutely crucial to take social aspects under consideration. The members' involvement, relations between the tenants and cultural norms influence the effectiveness of collective action. Those issues are especially important for professional property managers. The aim of the article is to present social aspects of managing HOAs in Poland.

The article presents the results of a study on the social aspects of HOA activity. It examines and compares three organizational models of HOAs in Poland. One of them is self-managing, with an active board of the association that operates without external help; this model requires a high level of volunteer commitment. The second model represents HOAs jointly managed by the board and a professional property manager; this type is heterogeneous - the allocation of tasks and relations between the two players vary according to the level of the board's engagement. The last type represents a HOA that was not able to establish a board, thus its role is played by a professional property manager. In all three types, both organizational structures and management methods depend on the level of the homeowners' engagement. The study indicates such engagement factors. HOAs are characterized by their typical operations, decision-making processes, information flow, the roles played by the board of the association and professional property manager, the level of volunteer commitment and neighborhood ties. The study also indicates satisfaction factors in terms of the property manager's service.
\end{abstract}

Key words: homeowner association, property management, urban governance.

JEL Classification: R31.

Citation: Szczepańska M., 2015, Social Aspects of Managing Homeowner Associations, Real Estate Management and Valuation, Vol. 23, No. 1, pp. 55-62.

DOI: 10.1515/remav-2015-0005

\section{Introduction}

In Poland, an increase in homeowner associations (HOAs) can be observed. A HOA is an organization established to manage and maintain common property in residential housing. It is established by people who own apartments located in one or a few neighboring buildings, and sometimes by the owners of houses in a neighborhood. It is organized on the principle of shared ownership of community property and facilities. The apartment owner also owns a corresponding share of common areas like the land, common facilities, staircases etc. HOAs maintain these common areas. The association collects membership fees and provides services, such as: repairs, cleaning, grass cutting or landscaping of commonly-owned green areas. The goods and services provided by HOAs vary across associations. Some of them have their own swimming pools, streets, parks, lakes, gyms or security. 
HOAs control the use of their private land by internal regulations. They also regulate the dwellers' behaviors. They can prescribe paint colors and Christmas decorations, ban pets, prohibit smoking cigarettes or drying laundry on the balcony. Membership in a HOA is automatic and mandatory. Buying an apartment or a house in a HOA automatically makes one a member and subject to the association's rules. An association is governed by an elected board and often hires a professional property manager. HOAs are called private governments because they do many things that governments do - hold elections, regulate behaviors, collect fees - just as governments collect taxes and deliver similar services.

HOAs are becoming the dominant form of housing developments. They are popular in many parts of the world (Glasze, WeBSTER, FRANTZ 2005, READ 2008), first emerging in the United States in the middle of the 19th century. The explosion in the number of HOAs began in the 1960s. Today, there are about 30 times more HOAs in the United States (about 323,000) than in 1970 (www.caionline.org/industrydata). The phenomenon of the growing popularity of HOAs can also be observed in Poland, where they emerged about twenty years ago under the provisions of the Act on the ownership of real estate units (ACT of 1994...). HOAs are very popular in newly built condominiums. Some of them have also emerged in multi-apartment buildings built by housingcooperatives under communism. Their members believe that they exercise greater control over the quality of service and the use of funds.

The article examines the social aspects of HOA activity that are important from the managerial point of view. The author claims that the members' involvement, the relations between the tenants and cultural norms influence the effectiveness of collective action. A professional property manager has to be aware of these issues. The aim of the article is to present social aspects and determinants of managing HOAs under Polish conditions (for public real estate management see GROSS, ŹRÓBEK 2013; MUCZYŃSKI, TURBACZEWSKA 2013). Taking an organizational approach, this article presents the results of the study on the social aspects of HOA activity. It examines and compares three organizational models of HOAs. In all three types, both organizational structures and management methods depend on the level of the homeowners' engagement. Thus, the study indicates engagement factors. HOAs are characterized by their typical operations, decision-making processes, information flow, the roles played by the board and professional property manager, the level of volunteer commitment and neighborhood ties.

\section{Literature review}

The spread of HOAs has elicited academic and political debate that is much polarized. Some authors have praised HOAs as efficient substitutes for municipalities (NELSON 2005) or as an ideal form of urban development that ensures the efficient provision of public services (FOLDVARY 1994). On the other hand, some authors portray HOAs as tools of exclusion (MCKENZIE 1994) and a part of the process of urban social disintegration (DAVIS 1990). This disjunction indicates the need to review the different arguments and perspectives on HOAs, especially considering that Polish scholars pay little attention to these new governance entities.

\subsection{Club economy}

HOAs provide the inhabitants with many collective goods and services, such as recreational facilities and cleaning or security services. These are called "club goods". HOA members pay for these goods and services by membership fees. The associations solve the problem of free-riders - only those who pay the respective fees, profit from the collective goods. This makes this form of government more effective than in the public sector. The self-administration of HOAs ensures a market-driven and efficient supply of goods and services for dwellers. Members of the associations decide how to spend their funds, choosing the goods and services they deem most necessary. Therefore, some authors claim that the spread of HOAs is an institutional innovation, the best form of urban development (FOLDVARY 1994). HOAs are called club economies (GLASZE 2004) because they are groups which collectively, though also exclusively, share the consumption of goods and services.

GLASZE explains why HOAs organized as club economies are attractive to home buyers, local governments and developers (GLASZE 2004). Developers market not only apartments, but also "the whole package": apartment, parking space, maintenance and access to club goods. Many home buyers look for such a package offer; they don't want to organize the neighborhood themselves, instead preferring someone to do it for them, while having full control over the process. The organizational 
structure of a HOA allows these expectations to be satisfied. Inhabitants profit from club goods and services that are usually higher quality than public ones. Home owners don't risk economic degradation of the neighborhood because a HOA has the power to exclude free riders and regulate the use of common spaces. Local governments profit from HOAs as they are self-financing and their members pay property taxes. These associations provide services that formerly had been provided by municipal agencies funded by property taxes, with members continuing to pay such taxes. Some observers even go as far as describing HOAs as "cash cows" (MCKENZIE 1994).

\subsection{Private urban governance}

HOAs can be viewed as private urban governments. In this perspective, the spread of HOAs can be described as the establishment of a new territorial organization on the sub-local level. How do HOAs shape civic life in urban areas? Can the residents' engagement in community activities be regarded as an expression of civic involvement? Some researchers argue that HOA membership involves taking part in the decision-making process. This gives the feeling of power and influence, increasing engagement in matters relating to the surrounding environment as well as strengthening civic attitude (i.e.: FOLDVARY 1994; WEBSTER 2002). Scientists researching gated communities which usually function as HOAs (BLAKEly, SNYDER 1997, CALDEIRA 2000, LOW, DONOVAN, GIESEKING 2012) claim that their residents provide everything they need themselves, including services, and are, therefore, not interested in paying for public services. They are not going to care about the improvement of the quality of such services and are not going to engage in actions leading to their improvement. Similarly Kohn (KOHN 2004) claims that the sense of belonging to a HOA results in a low sense of responsibility for the rest of the area or city.

\section{Social aspects of managing HOAs in Poland}

\subsection{Research methodology}

The article is based on the results of a study on social aspects of HOA activity conducted by the author (research financed by UE, EFS, POKL, Priority IV). It was organized as a cross-case study of seven associations located in a Polish, medium-sized city. Qualitative methods were adopted: in-depth interviews with board members, inhabitants and professional property managers, observations of HOA meetings, and the analysis of documents. Each of the 30 interviews was conducted in person, in the respondent's apartment or in the office of the HOA. Interviews ranged from 20 to 150 minutes, each being recorded. HOAs included in the study represent three main organizational models and three types of buildings (townhouses, old-type blocks of flats, and newly-built, modern blocks of flats). All of them were so called "big HOAs" - consisting of more than 7 apartments located in one building. The author attended five HOA meetings to observe the discussion of issues at hand, group decision-making processes and interactions between association members and the property manager. The analyzed documents included: the associations' bylaws, reports from annual meetings, budgets, and agreements between the association and the company responsible for the management of the property. In addition, four real estate agents were interviewed to determine the importance of HOAs to homebuyers.

\subsection{Three main organizational models of HOAs in Poland}

Although homeowners associations were run by a board in all of the analyzed cases, their internal organization varied. Based on this, three main types were established. One of them is self-managing, with an active board which operates with minimal external help, the only employee being a part-time bookkeeper. This model expects a high level of volunteer commitment, as well as technical and managerial skills. The board concludes contracts with private firms for cleaning, routine repair and renovation, prepares budget plans and conducts meetings. Board members are very involved, devoting a lot of their time to working for the HOA - some of them are retired. This type was represented by two cases. In one of these HOAs, the board members received reimbursement for their administrative work (the only such situation in the whole study). In the other one, board members carried out small repairs themselves, but received no salary.

The second model represents a HOA managed together, by the board and a professional property manager. This type is numerously represented, as most HOAs hire a management company to handle some daily responsibilities of the association. These companies usually handle the collection of dues 
and payment of contractors, sometimes they propose annual budget plans and advise on technical issues. Task allocation and relations between the board and property manager vary according to the level of board members' engagement. On the one hand, there are boards which are motivated to work for the community but lack technical skills and a knowledge of the law. They need a professional manager to ensure that they act correctly, requiring only advice. In many cases, members of the board have ideas what to change in the HOA and expect the property manager to put it into action. On the other hand, there are also boards with members who cannot devote time to work for the HOA. They expect the HOA to be managed by professionals, who they plan to check up on from time to time. In extreme cases, the board limits its participation to taking part in annual HOA meetings. Property managers usually prefer to cooperate with the boards involved. One of the managers describes an ideal situation: "This is how we cooperate and how cooperation between the board and the manager should look like. Firstly, tight control of financial matters, checking the bank statement once a month and verifying what the money was spent on, the state of the proceeds and whether there are any arrears. Then, discussing all the technical issues which have recently happened in the building. The Board, even if they want to make the decision independently, verifies it with us each time. We sort of oversee the entire budget; we know what it looks like. These relations, cooperation and conversations result in the real decisions taken by the Board."

The last type represents a HOA that couldn't establish a board, therefore its role is played by a professional property manager. In one of the analyzed HOAs all the members claimed that they work a lot and are unable to find time to serve as board members. Finally, nobody agreed to take on the responsibility and, as a result, a professional property manager acts as the board of the association consisting of one member. Each flat owner can verify his work, have access to all the documents and ask the manager for clarification. The dwellers rarely do so as they trust the manager. Despite the declared lack of time, large numbers of inhabitants participate in the meetings of the HOA, voicing their ideas and remarks; yet nobody is willing to assume the responsibility for putting them into practice.

\subsection{Information flow}

Most of the HOAs have one annual meeting of the whole association as well as monthly board meetings. Key information on income and expenses is distributed to all the owners in writing to their mailboxes once a year, before the annual meeting of the HOA. However it is customary for the majority of the analyzed HOAs to have informal information flow, which is the dominant form of communication. As one of the board members describes it, "The main source of information is hearing things on the grapevine. People talk. The second source is asking direct questions. Mr X, a member of the board or me - people ask us questions when they see us. We answer them each time individually. Twice a month, we are on duty in the office. We wait for any remarks and issues to arise. Nobody comes." Right beside every entrance to the stairwell there is a message board containing phone numbers to board members, the property manager, and sometimes to the handymen. The owners appreciate quick and direct contact with the property manager. It is only natural for them to call them the instant a problem or question arises. This is the way of raising maintenance issues and dealing with all the formalities. Such a means of communication is convenient for the inhabitants. However, it can be bothersome for the property manager as the dwellers call him on his mobile phone outside of office hours.

The research conducted earlier by the author on internet forums of HOAs ("Gated communities: the awareness-related aspects of socio-spatial divisions and neighbourhood ties", www.socialspacejournal.eu) shows that they can be a comfortable means of communication. On the forum, there is a possibility to exchange ideas between the dwellers and the property manager, who can also hold the role of the forum administrator. Such forums serve as message boards and allow discussion similar to that of meetings to be carried out. The advantage of such a forum is that participation does not require the presence of all parties in one place at the same time. This creates an opportunity for those who work a lot and do not usually attend the meetings to be more actively involved. The primary obstacle to using an internet forum in a HOA is the fact that not all the dwellers are able to use a computer and the internet. This is why internet HOA forums exist primarily in big cities and new buildings, which tend to be inhabited by young people possessing such abilities.

\subsection{Decision-making processes}

Most associations meet once a year to vote on a budget and elect board members. HOA members usually discuss funding priorities and organizational issues during these meetings. In most of the 
observed cases, the atmosphere was friendly but a few of these meetings were characterized by a confrontational manner. A common pattern of the decision-making process is informal discussion among HOA members followed by an official vote, the result of which is not surprising as everybody knows that the resolution is going to be accepted. Such discussion, accompanied by persuasion, usually takes place before the official meeting, during daily neighborly chats. As one of the HOA members describes it, "We see each other every day, in the lift, in the stairwell, and this is when we talkpeople persuade each other. So when it comes to the vote, everything has already been decided and the vote is a pure formality." The analyzed documents confirm this observation. In $70 \%$ of the cases, all the voting members were unanimous in their decision. This might also suggest that the issues voted on were not controversial.

\subsection{Members' opinions on HOAs, efficacy criteria}

Members of the researched HOAs were mainly pleased about this form of organization. They pointed to a greater efficacy of the management process in comparison to traditional housingcooperatives created during the communist times. Efficacy was measured by the ratio of monthly rent payments to the quality of services contracted by HOAs. The respondents emphasized greater control over the quality of services and the use of funds. They were also pleased with the high transparency of the management process, "A friend of mine also lives in this type of building, has a flat of the same size but managed by a housing-cooperative. She pays $200 \mathrm{zl}$ more and doesn't even know what is happening with this money. We know everything, we vote, we approve and we have control over all of the costs and expenditures..."

Some respondents explain the greater efficiency of HOAs by their smaller scale. HOAs usually manage one building, whereas housing-cooperatives govern entire residential districts. "If there is a HOA, as we have it, there is no overgrown bureaucracy, the offices and clerks who need to be paid for." In one of the HOAs where the building previously belonged to a cooperative, the inhabitants highlight that the condition of the building and its surroundings improved when the HOA was created, "Before the HOA, there was nothing, not even a sidewalk, just mud in front of the building. When we became a HOA we somehow gathered money and created a maintenance fund. So everything has changed for the better: we have benches, a green area, the building has been renovated and insulated. Another result of this is that it became calmer and safer - we had CCTV installed and it has become more peaceful here."

The presence of a HOA, however, isn't a very important part of the decision to purchase a flat. Interviewed real estate agents estimated that a little less than a half of all homebuyers realize what a HOA is. Some buyers believe that membership fees are lower in a HOA than in a housing-cooperative and that is the main difference they focus on.

The criteria of the efficiency of a HOA used by the inhabitants to evaluate it are also important. One of them is the ratio of the rent to the quality of the service provided. What is more, the homeowners evaluate the HOA based on: what had been done, how much maintenance and refurbishment has been carried out, the appearance of the building and whether or not everything is running smoothly. The aesthetics of the building were mentioned in a couple of the interviews. According to some respondents, the HOA functions well if the building is insulated and painted, the staircases are clean, the basement is kept tidy and the area surrounding the building is green and wellmaintained. Some people also pointed to good relations and harmony between the inhabitants as a criterion determining the efficiency of the HOA.

\subsection{Residents' involvement}

The residents' involvement is crucial to the functioning of a HOA. It manifests itself mainly by attendance at HOA meetings. This is where the inhabitants discuss matters relating to the building, plan expenditures and investments, vote, and make decisions. Everything is connected with being actively interested in the building and feeling responsible for the property. HOAs give the owners an actual possibility to influence what is happening in their neighborhood. As a result, we could expect their substantial involvement in the functioning of the HOA. However, this is not the case. In the majority of cases, we can talk about a passive majority and active minority. Low involvement results in the inability to pass resolutions during HOA meetings due to the insufficient number of homeowners present. This is always explained in a similar way: the lack of time. Sometimes the owners are discouraged to take part in the meetings by neighborly disputes. On the other hand, those who are involved in the HOA are motivated by the fact that they feel like owners and are responsible for their property and surroundings. 
Changes can be observed in the level of involvement in HOAs. It is usually high when the HOA is first set up, when all the important issues are decided on. If everything goes smoothly and no major problems arise, the inhabitants place trust in the board and the property manager, and interest wanes. It may rise again in the case of conflicts or decisions relating to big investments. As one of the members puts it, "If you don't want any money, nobody is interested."

From the perspective of how a HOA functions, it is the board that is the most important. The board's involvement is what makes the whole organization efficient. The members of the board decide how much time they want to devote to the HOA and how they want to manage it. Very often, they also transfer their own private habits regarding time management and the organization of work and the workplace onto the HOA. The style of performing this function is also influenced by individual personality features. Thus, the end effect of how a HOA is managed depends on many factors. This in turn influences the model of cooperation with the property manager. The analyzed HOAs are different in terms of the level of board involvement. What is distinctive is that the most actively involved board members are the retirees, who have an abundance of free time. What motivates people to devote their time to a HOA is usually their attachment to the place and the feeling of responsibility. In the interviews, some of the board members indicate feeling that if they are not going to take care of something, it is not going to get done at all or well enough. Rows with neighbors and negative feelings towards the board, on the other hand, were discouraging factors. There was an instance when the inhabitants accused the board of an autocratic management style and deriving private benefits from the function. They felt as though the HOA was being used as if it belonged to the board members.

\subsection{Bonds between neighbors}

A bond between neighbors is understood here as defined by Piotr Kryczka, i.e. "a system of relatively stable connections and relationships between people, resulting from the proximity of living and expressing itself in the form of regulated activities, which assume certain obligations and rights of both parties" (KRYCZKA 1981). Nationwide research as well as a study carried out in a single city confirm the popular belief that the most popular type of neighborhood bond is one referred to as "conventional", based on saying "good morning" when passing by or short chats (KALTENBERGKWIATKOWSKA 2002, ŚWIĄTKIEWICZ 2004, BŁASZCZYK 2007, CBOS 2008). One might expect that the organizational form of a HOA would result in more frequent contacts and closer relationships between neighbors (GUEST, COVER, MATSUEDA, KURBIN 2006). However, the research quoted does not confirm such a hope. The formation of HOAs does only a little to bring the inhabitants closer. In rare cases, relations between neighbors establish mutual help. This usually includes receiving a parcel, borrowing or lending some lacking food items, or sometimes watching the flat during an absence. Respondents rarely ask for such help, but have the feeling that if the need arose, they could count on it, "If I needed it, they wouldn't say no. I wouldn't refuse, so I don't think others would either."

\subsection{Property manager service satisfaction factors}

What is satisfaction from the services of a property manager based on? In the interviews, a number of factors emerged, with two of them found to be predominant: professionalism and helpfulness. A good property manager is seen as a trustworthy professional in areas ranging from building matters, technical issues, and construction law, to management and finance. "I was looking for (...) a property manager and visited a few, and out of the ones I contacted, Mr. X was to my liking due to his knowledge of housing administrative procedures and the law. He is nice and friendly, and we are still in such contact today. (...) The cooperation is running smoothly". Social competences of the property manager, such as: helpfulness, good communication skills, the ability to chair a meeting, or the ability to resolve a conflict, play an important role.

Another aspect of satisfaction which influences the evaluation of a property manager is his or her efficiency of work. Respondents value the possibility of contacting a single person with matters relating to the flat and being able to deal with everything in one place very much. "We used to have a military housing-cooperative. And I told them no, because I had been with them for one year. (...) You had a separate person for gas, separate for water, separate for electricity, separate for garbage disposal and every one of them had an office. Whoever you were trying to visit was always out of the office and you could never be reached. And because of this I don't want to, and I am not going to, pay for you, because I don't need you. Now we have one person dealing with everything. I am going to take one person, pay him, tell him what I expect to be done, confirm it in writing and pass a resolution on it, and I will keep using his services." 
Cooperation with the property manager is influenced by the attachment of owners to their dwelling. Inhabitants have an emotional bond with the flat, building and neighborhood. Additionally, the pride that comes from ownership strengthens this emotional attachment. Therefore, emotions also play a role when choosing the property manager. It is important for the property manager to be involved and show genuine care about the building. Involvement and professionalism are, according to social psychologists, the two elements of expert power (FRENCH, RAVEN 1959). People follow the expert's suggestions, seeing as how: 1) he is a professional possessing specialized knowledge, 2) they believe that he has good intentions and is going to use his knowledge for their benefit. People who are not involved in the functioning of a HOA and do not know the details of what is happening, having no other possibilities of evaluating the property manager's work tend to judge him based on the frequency of visits to the HOA. For this category of owners, the recognizability of the property manager is important as well as his "visibility". It is important to have the possibility to see and meet him when he is overseeing the works on the property. Therefore, knowing someone "by sight" and the awareness that the property manager visits the building from time to time is of importance. "You can see him here very often, especially when there are some works being carried out. He oversees everything. He's such a hard-working person."

\section{Conclusions}

The studied cases of HOAs showed that relations between association members, the board and the property manager vary according to the organizational model of the association and the level of the members' involvement. On the whole, members of the researched HOAs are pleased about this form of governance. They emphasize a high efficiency of the management process, control over the quality of service and the use of funds, and the high transparency of the management process. However, in most of the studied cases the level of the members' involvement is low. The homeowners' explanations are similar: lack of time. Sometimes the members are discouraged from taking part in HOA meetings by disputes between neighbors. On the other hand, the feeling of ownership is a motivating factor. The level of satisfaction from the services provided by the property manager is based mainly on his or her perceived professionalism and social competences: helpfulness, good communication skills, ability to chair a meeting, and ability to resolve a conflict.

\section{References}

BLAKELY E., SNYDER M., 1997, Fortress America: Gated Communities in the USA, Brookings Institution Press, Washington DC, Cambridge.

BŁASZCZYK M., 2007, O więzi sąsiedzkiej w środowisku wielkomiejskim (On Neighbourly Bond in the Big City Environment), [in]: Współczesna socjologia miasta. Wielość oglądów i kierunków badawczych dyscypliny (Contemporary Sociology of the City. The Multitude of Aspects and Research Options of the Field), Ed. I. BOROWIK, K. SZTALT, Wydawnictwo Uniwersytetu Wrocławskiego, Wrocław.

CALDEIRA T., 2000, City of Walls: Crime, Segregation, and Citizenship in Sa o Paulo, University of California Press, Berkeley.

CBOS, 2008, Kontakty sąsiedzkie w miejscu zamieszkania. Komunikat z badań (Neighbourly Contacts in the Place of Residence), M. SKRZESZEWSKI.

DAVIS M., 1990, City of Quartz: Excavating the Future in Los Angeles, Verso, London.

FOLDVARY F., 1994, Public Goods and Private Communities: The Market Provision of Social Services, Edward Elgar, London.

FRENCH J., RAVEN B., 1959, The Bases of Social Power, [in]: Group dynamics, Red. CARTWRIGHT D., ZANDER A., Harper \& Row, New York.

GLASZE G., 2004, Some Reflections on the Economic and Political Organisation of Private Neighbourhoods, Housing Studies, Vol. 20, No. 2, March 2005, pp. 221-233.

GLASZE G., WEBSTER C., FRANTZ K., 2005, Private Cities: Global and Local Perspectives, Routledge.

GROSS M., ŹRÓBEK R., 2013, Public Real Estate Management in Post-Socialist Countries, Real

Estate Management and Valuation, Vol. 21, No. 4, pp. 11-16.

GUEST A., COVER J., MATSUEDA R., KURBIN Ch., 2006, Neighborhood Context and Neighboring Ties. City \& Community, 5, 4 .

McKENZIE E., 1994, Privatopia: Homeowner Associations and the Rise of Private Government, Conn.: Yale University Press, New Haven. 
KOHN M., 2004, Brave New Neighborhoods: The Privatization of Public Space, Routledge, New York.

KRYCZKA P., 1981, Społeczność osiedla mieszkaniowego w wielkim mieście. Ideologie i rzeczywistość (Housing Estate Community in a Big City. Ideologies and Reality), PWN, Warszawa.

KALTENBERG-KWIATKOWSKA E., 2002, Sasiedztwo we wspótczesnym mieście - stereotypy $i$ rzeczywistość (Neighbourhood in a contemporary city - stereotypes and reality) W: Stare i nowe struktury społeczne w Polsce, t. III Czynniki miastotwórcze w okresach wielkich zmian spotecznych (Old and New Social Structures in Poland, Vol. III Urbanization Factors at Times of Major Social Changes), Red. MISZTAL J., STYKA, UMCS, Lublin.

LOW S., DONOVAN G., GIESEKING J., 2012, Shoestring Democracy: Gated Condominiums and Marketrate Cooperatives in New York, Journal on Urban Affairs, Vol. 34, No. 3, pp. 279-296.

MUCZYŃSKI A., TURBACZEWSKA A., 2013, The Concept of Displacement of Tenants in the

Management of Housing Stock, Real Estate Management and Valuation, Vol. 21, No. 4, pp. 26-35.

NELSON R. H., 2005., Private Neighborhoods and the Transformation of Local Government, DC: Urban Institute Press, Washington.

READ B., L., 2008, Assessing Variation in Civil Society Organizations: China's Homeowner Associations in the Comparative Perspective, Comparative Political Studies. Sep. 2008, Vol. 41 Issue 9, pp. 1240-1265.

ŚWIĄTKIEWICZ W., 2004, Więzi sąsiedzkie i życie publiczne (Neighbourly bond and public life) W: Obywatel w lokalnej społeczności. Studia i szkice socjologiczne (Citizen in the Local Society. Sociological Studies and Drafts), ed. M. S. SZCZEPAŃSKI, WSZiNS, UO, Tychy, Opole.

SZCZEPAŃSKA M., 2011, Osiedla grodzone: świadomościowe aspekty podziałów społeczno-przestrzennych i więź sąsiedzka (Gated Communities: Awareness-Related Aspects of Socio-Spatial Divisions and Neighbourhood Ties), www.socialspacejournal.eu 10.11.2013.

Ustawa z dnia 24 czerwca 1994 r, o własności lokali, Dz.U. nr 85 z dnia 27.07 .1994 r., poz. 388 z pózn. zm. (Act of 1994, 24 June on the Ownership of Real Estate Units, Journal of Laws, 1994, No. 85, item 388 , as amended).

WEBSTER C., 2002, Property Rights and the Public Realm: Gates, Green Belts and Gemeinschaft, Environment and Planning B, 29, pp. 397-412. 